\title{
RATES AND APPLICATION TIMES OF NITROGEN IN PROSO MILLET CROP
}

\author{
DOSES E ÉPOCAS DE APLICAÇÃO DE NITROGÊNIO NA CULTURA DO PAINÇO
}

\section{Claudir José BASSO ${ }^{1}$; Lucindo SOMAVILLA ${ }^{2}$; Antônio Luis SANTI'; Fabiane Pinto LAMEGO ${ }^{1}$; Braulio Otomar CARON ${ }^{1}$; Dionei Schmidt MURARO ${ }^{3}$; Edivan PANSERA ${ }^{3}$; Rodrigo Ferreira da Silva ${ }^{1}$}

1. Professor, Doutor, Departamento de Ciências Agronômicas e Ambientais, UFSM, Campus de Frederico Westphalen, RS, Brasil, claudirbasso@gmail.com; 2. Mestrando do Programa de Pós Graduação em Agronomia: Agricultura e Ambiente (PPGAA), UFSM, Campus de Frederico Westphalen, RS, Brasil; 3. Estudante do curso de Agronomia, UFSM, Campus de Frederico Westphalen, RS, Brasil.

ABSTRACT: Due to its rapid growth, drought tolerance and short cycle, the proso millet crop has attracted the attention of producers and technicians as an alternative to crop rotation and formation of straw for subsequent planting of soybean in no-tillage system in some regions of the state of Rio Grande do Sul (RS), Brazil. However, there is limited information on application times and rates of nitrogen $(\mathrm{N})$. Therefore, the objective of this study was to evaluate application times and rates of $\mathrm{N}$ in proso millet crop, under some plant parameters and in the final grain yield. The experiment was conducted in the Federal University of Santa Maria, campus of Frederico Westphalen, in the period of September to November2012. The experiment design was that of randomized blocks, in a4 $\mathrm{x} 4$ factorial design, with four replications. The treatments consisted of the combination of four rates of $\mathrm{N}$ (zero, 30, 60 and $90 \mathrm{~kg} \mathrm{ha}^{-1}$ ) and four different application times of $\mathrm{N}$ : all at sowing, $30 \%$ at sowing and the remaining 15 days after emergence (DAE), $30 \%$ at sowing and the remaining 30 days DAE, $30 \%$ at sowing and the remaining45 days DAE. There was no significant response as regards the application times of Nin the proso millet crop. On the other hand, there was a significant and linear response in plant height, dry matter production, stem diameter, panicle length and in the final grain yield within crease in rates of $\mathrm{N}$.

KEYWORDS: Nitrogen management. Plant parameters. Grain yield.

\section{INTRODUCTION}

Proso millet (Panicum miliaceum L.) is a short cycle crop and has been cultivated in states such as São Paulo and Mato Grosso do Sul with the objective of producing grain replace birdseed in the feeding of birds in captivity (ZANCANELLA et al., 2003).

Besides water deficit, nitrogen has been appointed as the second most limiting factor in agricultural production (DATE2000; GRAHAM; VANCE, 2000). According to Simili et al. (2008), variability in crop management and environmental conditions associated with complex dynamics of $\mathrm{N}$ in soil (mineralization/immobilization, volatilization, leaching and denitrification) can cause major changes in its availability to plants (RAMBO et al., 2004).

Soratto et al. (2004) observed an increase in plant height, number of stems per plant and grain yield while studying $\mathrm{N}$ topdressing in millet culture in greenhouse. On the other hand, at field level, Soratto et al. (2007) while studying four $\mathrm{N}$ rates and two application times, observed that topdressing increased plant height, panicle length and consequently millet grain yield.
Studies in literature address the correct time of application seeking greater synchrony between availability and uptake in wheat crop (BREDEMEIER; MUNDSTOCK, 2001; SANGOI et al., 2007). Some of these studies indicate that the installments of $\mathrm{N}$ result in higher recovery of nutrient by the culture and higher yield compared to a single application(SANGOI et al., 2007, WAMSER; MUNDSTOCK, 2007, MEGDA et al., 2009), contradicting observations of Coelho et al. (1998), where the splitting of $\mathrm{N}$ was not advantageous in wheat crop. Therefore, the proportion of the installment should consider factors such as the environment, management, and culture in order to obtain specific and not generalized recommendations (ESPINDOLA et al., 2010).

In Rio Grande do Sul (RS, Brazil)the cultivation of proso millet has attracted attention as an important alternative to wheat rotation, because in addition to straw production, there is enough time for harvesting and sowing of soybean within the recommended zoning for the culture. However, there is little or no information as to the rate and timing of $\mathrm{N}$ application in this culture. Therefore, the aim of this study was to evaluate application times and rates of $\mathrm{N}$ in proso millet crop under some plant parameters and in the final grain yield. 


\section{MATERIAL AND METHODS}

The experiment was conducted in the Federal University of Santa Maria, campus of Frederico Westphalen, RS. The soil is classified as Rhodic Eutrudox, (EMBRAPA2006)and at the time of installation of the experiment it presented the following characteristics in the $0-0.20 \mathrm{~m}$ layer: $\mathrm{pH}$ in $\mathrm{H}_{2} \mathrm{O}(1: 1) 4.8$, SMP 5,5 , clay $650 \mathrm{~g} \mathrm{~kg}^{-1}$, organic matter $29 \mathrm{~g} \mathrm{dm}^{-3}$, Mehlich - P 13.0mg dm ${ }^{-3}$, potassium $252 \mathrm{mg} \mathrm{dm}^{-3}$, calcium $3.1 \mathrm{cmol}_{\mathrm{c}} \mathrm{dm}^{-3}$, magnesium $1.7-\mathrm{cmol}_{\mathrm{c}} \mathrm{dm}^{-3}, \mathrm{H}+\mathrm{Al} 5.6 \mathrm{cmol}_{\mathrm{c}} \mathrm{dm}^{-3}$, Al 1,0 $\mathrm{cmol}_{c} \mathrm{dm}^{-3}$, CTC $11,3 \mathrm{cmol}_{\mathrm{c}} \mathrm{dm}^{-3}$, and a percent of base saturation of CEC and $\mathrm{Al}$ of $50.6 \%$ and $14.8 \%$, respectively.

Six months prior to the installation of the experiment, there was an application of limestone to increase $\mathrm{pH}$ to 6.0 in water following the recommendation of the Commission of Chemistry and Soil Fertility in the states of Rio Grande do Sul and Santa Catarina, Brazil(CQFS-RS/SC2004).

The experiment design was that of randomized blocks, in $4 \times 4$ factorial design, and treatments consisted of four rates of nitrogen (zero, 30,60 and $90 \mathrm{~kg} \mathrm{ha}^{-1}$ ) and four application times (allat sowing, $30 \%$ at sowing and the remaining 15 days after emergence (DAE), $30 \%$ at sowing and the remaining $30 \mathrm{DAE}, 30 \%$ at sowing and the remaining $45 \mathrm{DAE}$ ). Such $\mathrm{N}$ application was always done by casting for each plot, which measured $3 \mathrm{x}$ $2 \mathrm{~m}$, using urea as source.Phosphorus $\left(50 \mathrm{~kg} \mathrm{P}_{2} \mathrm{O}_{5}\right.$ $\mathrm{ha}^{-1}$ ) and potassium $\left(40 \mathrm{~kg} \mathrm{~K}_{2} \mathrm{O} \mathrm{ha}^{-1}\right)$, fertilization was done by casting five days prior to sowing using triple super phosphate and potassium chloride respectively, following recommendation of CQFS$\mathrm{RS} / \mathrm{SC}(2004)$.

The experiment was conducted under soybean stubble harvested in March and the sowing of AL Tibagi variety proso millet performed manually on September 5, 2012 at a spacing of $0.17 \mathrm{~m}$ between row and density of 80 seeds per linear meter. Upon full flowering, an area of $0.25 \mathrm{~m}^{2}$ was sampled in order to evaluate dry matter and accumulation of $\mathrm{N}$ in the shoots of millet. In order to do this, plant samples were taken to the greenhouse with air circulation and temperature of $65^{\circ} \mathrm{C}$ for drying until they reached constant weight. After weighing and dry matter determination, the samples were grounded and prepared for laboratory analysis of $\mathrm{N}$ following the methodology described by Tedesco et al.(1995).

The following evaluations were done days prior to the harvest. Plant height: average distance between soil surface and top of the highest panicle in 10 random plants within the area of each plot. Panicle length: average distance between the insertion of the first branch of the rachis and upper end of the panicle in 10 random plants within the area of each plot. Number of panicles per $\mathrm{m}^{2}$ : counting of the average number of panicles in 1 linear meter in two random lines of each plot. Number of grains per panicle: obtained by counting the number of grains in three panicles randomly collected in the area of each plot. Weight of a thousand seeds: random sampling and weighing of five samples of 500seed from each plot and the values were corrected to $13 \%$ moisture. Grain yield: assessed by manual picking of 8 central lines, discarding $0.5 \mathrm{~m}$ from each end of the plot $\left(2.7 \mathrm{~m}^{2}\right)$ and performing the track with a tractor and equipment weight adjusted to $13 \%$ moisture.

The results were submitted to variance analysis (in $4 \times 4$ factorial design) and significance was found for the variables analyzed, the averages were compared by the Tukey test at 5\%. For rates of $\mathrm{N}$, regression analysis was done, adjusting to the significant degree of the equation.

\section{RESULTS AND DISCUSSION}

Figure 1 shows that from emergence to harvest there were 75 days of crop cycle with distribution of rainfall conductive to the development of culture. Most of which concentrated in the month of October, which facilitated management of $\mathrm{N}$, applying urea in the late afternoon on wet soil primarily seeking to minimize $\mathrm{N}$ losses by ammonia volatilization.

In relation to the timing of topdressing, Table 1 shows that there was no significant effect on dry matter production. For plant height, application of $30 \%$ at sowing and the remaining at $45 \mathrm{DAE}$ showed the greatest height, which did not differ significantly from treatments at 15 and 30 DAE. Furthermore, working with application times and $\mathrm{N}$ levels in the millet culture, Soratto et al. (2007) found that regardless of the time (14 and 28 DAE), $\mathrm{N}$ application increased plant height. The same observation found by Soratto et al. (2004).As for stem diameter, similarly to plant height, the highest value was observed in the treatment with $\mathrm{N}$ application at $45 \mathrm{DAE}$, which did not differ significantly from treatment with $\mathrm{N}$ topdressing at 30 DAE. 


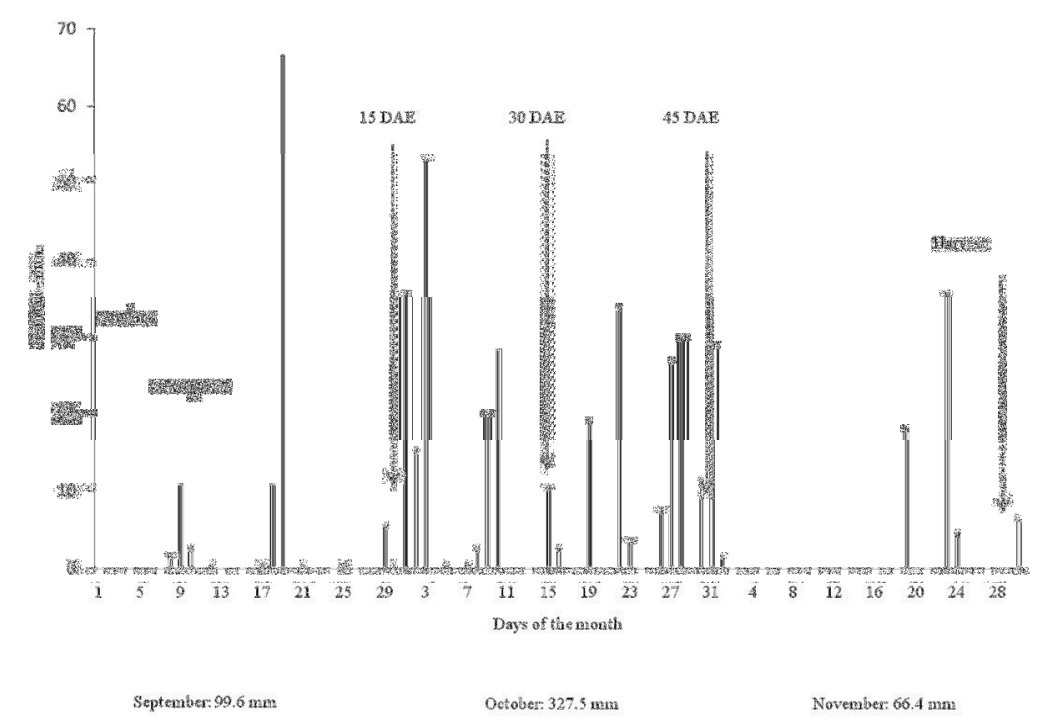

Figure 1. Daily rainfall during the experiment and dates for sowing, emergence, $\mathrm{N}$ management and millet harvest. Data obtained from the weather station of the UFSM, Campus of Frederico Westphalen, RS (Center for weather forecasting and climate studies/National Institute for Space Research CPTEC/INPE).

Table 1. Dry matter production, plant height, stem diameter, panicle length, number of grains per panicle in relation to $\mathrm{N}$ topdressing management of millet in relation to management of $\mathrm{N}$. Frederico Westphalen, RS.

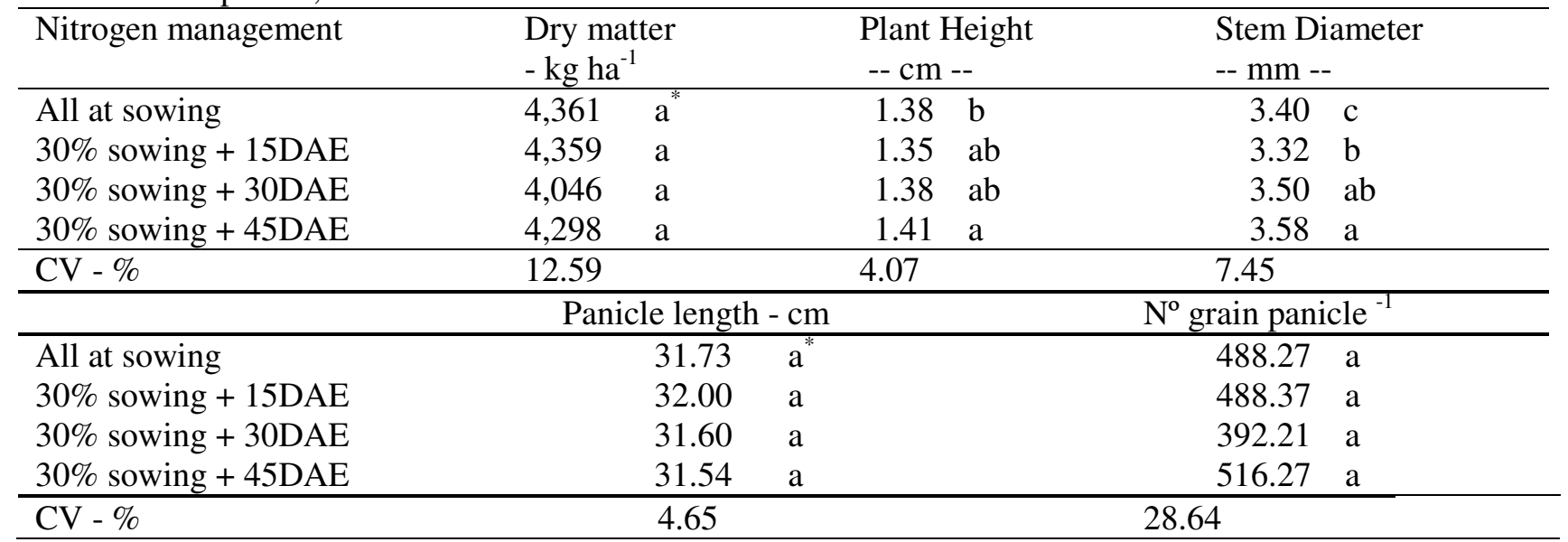

* Averages followed by the same letter do not differ by the Tukey test at $5 \%$ probability.

Comparing rates of $\mathrm{N}$, Figure 2 shows a linear increase in plant height, stem diameter, dry matter production and $\mathrm{N}$ accumulation in shoots of millet with the increase in $\mathrm{N}$ levels. This differs from that described by Soratto et al. (2007), where linear increase was only observed in plant height with the increment of $\mathrm{N}$ rates up to 14 DAE, showing quadratic response with $\mathrm{N}$ application at 20 DAE (booting).As for the production of dry matter and accumulation of $\mathrm{N}$ in the shoots, the increase was of 22.6, 15.3, and $48.6 \%$ and 19.2, 15.0 and $35.0 \%$, respectively for the levels of 30,60 and 90 $\mathrm{kg} \mathrm{N}$ ha ${ }^{-1}$ compared to the control.
Heringer and Moojen (2002), working with millet crop and evaluating increasing rates of $\mathrm{N}$ that ranged from 0 to $750 \mathrm{~kg} \mathrm{ha}^{-1}$ on millet dry matter yield, observed through the regression equation, that the rate of $464 \mathrm{~kg} \mathrm{~N} \mathrm{ha}^{-1}$ provided the highest production of forage. For the authors, the increasing response up to this rate observed in this study, shows that the $\mathrm{N}$ supply in soil does not meet the potential growth of summer grasses, which can justify linear response with increase in $\mathrm{N}$ rates in all parameters evaluated and shown in Figure 2. 

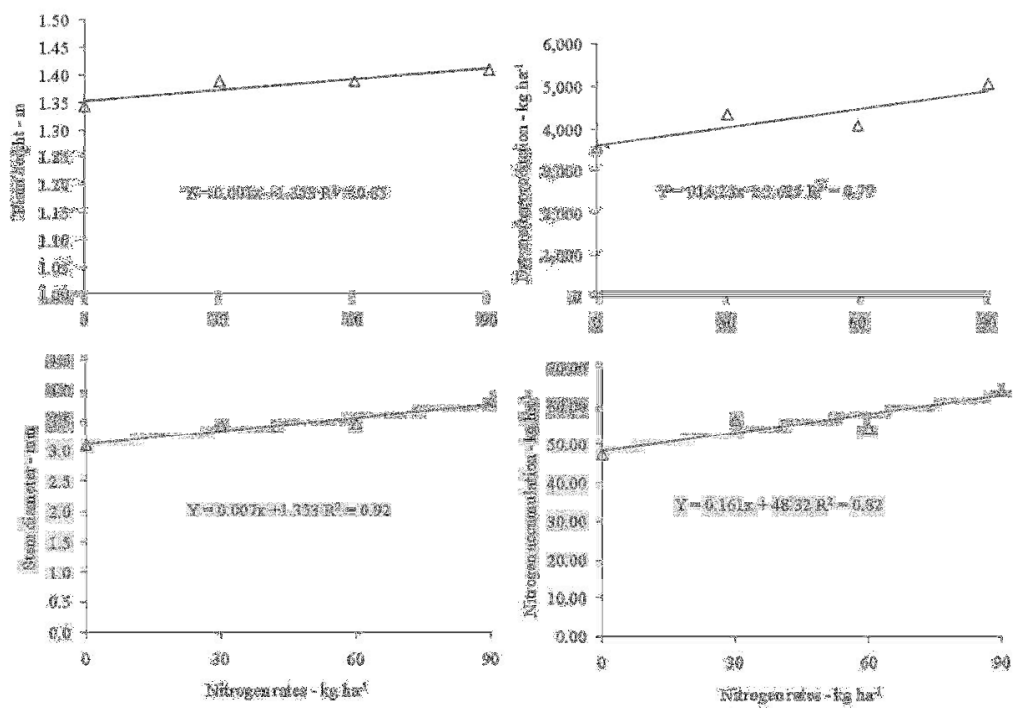

Figure 2. Plant height, stem diameter, dry matter production and $\mathrm{N}$ accumulation in millet submitted to different nitrogen rates. Frederico Westphalen, RS.

There was no significant effect on the length and number of grains per panicle, thousand seed weight and millet grain yield for application times of $\mathrm{N}$ (Table 1). As for panicle length and grain yield, linear response was observed with increasing levels of N (Figure 3).
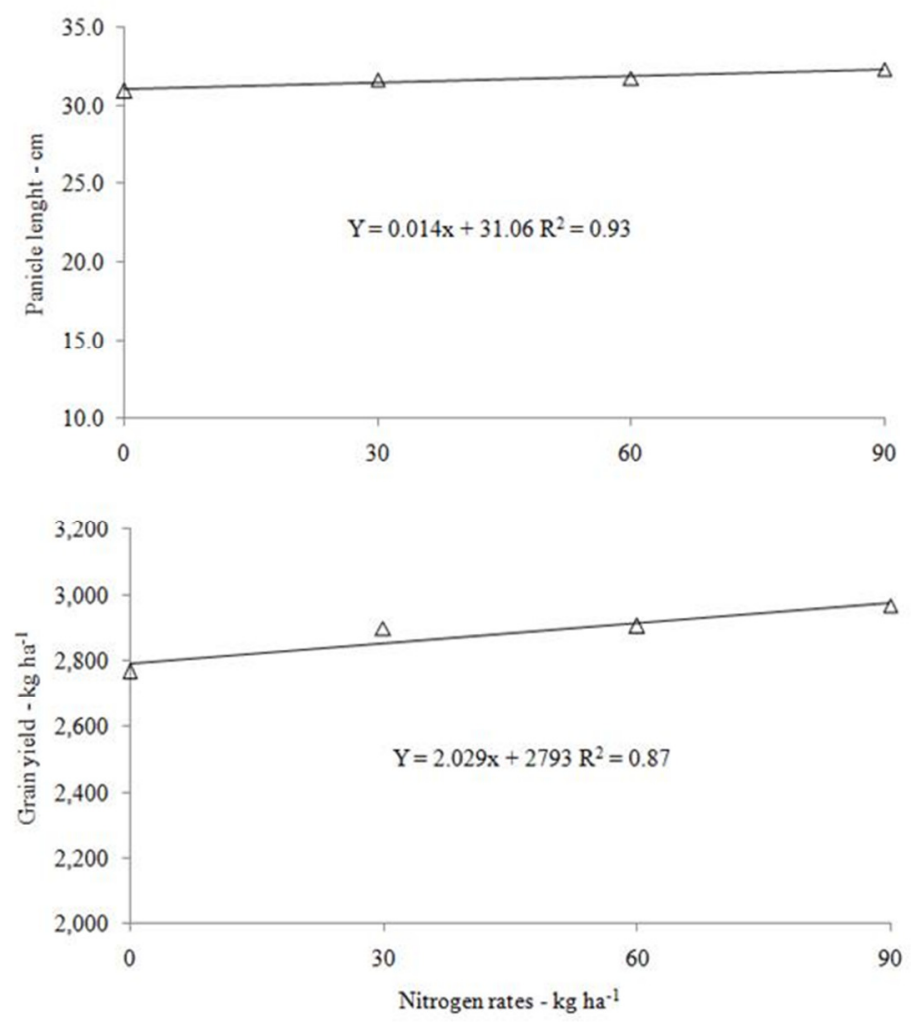

Figure 3. Panicle length and grain yield under different nitrogen rates in millet culture. Frederico Westphalen, RS.

With respect to panicle length, data presented in this study differ from that observed by Soratto et al. (2007), where a better response to this variable was found with the $\mathrm{N}$ application at 14 DAE compared to the application at 28 DAE. The authors justify that this is related to greater availability of $\mathrm{N}$ at the time of panicle differentiation. The $\mathrm{N}$ application, regardless of the time, increased panicle length as observed by JORNADA et al. (2005) as well.

As for the weight of a thousand seeds, Table 2 shows that there was no significant response to 
application times, supporting other studies (JORNADA et al., 2005; SORATTO et al., 2007).As for millet grain yield, there was no significant response to the different application times (Table 2). Espindola et al. (2010) working with two rates and two application times at sowing and topdressing (start of tillering) in wheat, observed that the installments promoted greater lodging and brought no benefit to wheat grain yield.

Table 2. Thousand seed weight and millet grain yield in relation to $\mathrm{N}$ topdressing management in relation to the management of nitrogen.

\begin{tabular}{lrlrll}
\hline Nitrogen management & Thousand seed weight $-\mathrm{g}$ & \multicolumn{2}{c}{ Grain yield $-\mathrm{kg}^{-1}$} & \\
\hline All at sowing & 2.34 & $\mathrm{a}$ & 2,707 & $\mathrm{a}$ \\
$30 \%$ at sowing + 15DAE & 2.29 & $\mathrm{a}$ & 2,910 & $\mathrm{a}$ \\
$30 \%$ at sowing + 30DAE & 2.17 & $\mathrm{a}$ & 2,919 & $\mathrm{a}$ \\
$30 \%$ at sowing + 45DAE & 2.31 & $\mathrm{a}$ & 3,001 & $\mathrm{a}$ & \\
\hline CV - \% & 4.65 & 11.79 & &
\end{tabular}

* Averages followed by the same letter do not differ by the Tukey test at $5 \%$ probability.

Regardless of the application time (14 and 28 DAE), Soratto et al. (2007) found positive response in millet grain yield with $\mathrm{N}$ topdressing. However, it showed linear response to $\mathrm{N}$ application at $14 \mathrm{DAE}$ and quadratic response to $\mathrm{N}$ application at 28 DAE. These authors also observed a maximum yield adjusted by the equation for the rate of $88.3 \mathrm{~kg}$ $\mathrm{ha}^{-1}$ of $\mathrm{N}$, which differs from that observed in Figure 3 , where there was a linear response to increasing rates of $\mathrm{N}$.

Considering the rate of $88.3 \mathrm{~kg} \mathrm{ha}^{-1}$ as maximum grain yield in the study of Soratto et al. (2007), who worked with a maximum rate of $120 \mathrm{~kg}$ $\mathrm{ha}^{-1}$, and the highest rate in this paper being $90 \mathrm{~kg}$ $\mathrm{ha}^{-1}$ may explain the linear response for many of the variables analyzed, inferring that millet responds to higher rates than those studied in this work.

\section{CONCLUSIONS}

There was no significant response as regards application time in the proso millet culture. However, there was significant and linear increase in plant height, stem diameter, panicle length and final grain yield with the increase in rates of $\mathrm{N}$.

Proso millet seems to respond to levels higher than $90 \mathrm{~kg}$ de $\mathrm{N}$ ha 1 with two application times: at sowing and 15 days after emergence.

RESUMO: A cultura do painço pelo seu rápido crescimento, tolerância a seca e ciclo curto, tem despertado atenção de produtores e técnicos como alternativa de rotação de cultura e formação de palhada para posterior semeadura da soja no sistema plantio direta em algumas regiões do Rio Grande do Sul. No entanto, são escassas as informações sobre a época de aplicação e doses de nitrogênio $(\mathrm{N})$. Por isso, o objetivo desse trabalho, foi avaliar épocas de aplicação e doses de $\mathrm{N}$ na cultura do painço, sobre alguns parâmetros de planta e na produtividade final de grãos. O experimento foi desenvolvido na Universidade Federal de Santa Maria, Campus de Frederico Westphalen, no período de setembro a novembro de 2012. O delineamento experimental foi de blocos ao acaso, num esquema fatorial $4 \mathrm{x} 4$, com quatro repetições, sendo os tratamentos constituídos da combinação de quatro doses de $\mathrm{N}$ (zero, 30, 60 e $90 \mathrm{~kg} \mathrm{ha}^{-1}$ ) e quatro diferentes épocas de aplicação do N: todo na semeadura, 30\% na semeadura e o restante 15 dias após a emergência (DAE), $30 \%$ na semeadura e o restante 30 dias DAE, $30 \%$ na semeadura e o restante 45 dias DAE. Não houve resposta significativa quanto à época de aplicação de $\mathrm{N}$ na cultura do painço. Houve uma resposta significativa e linear na altura de planta, produção de matéria seca, diâmetro do colmo, comprimento da panícula e no rendimento final de grãos com o aumento nas doses de $\mathrm{N}$.

PALAVRAS-CHAVES: Manejo de nitrogênio. Parâmetros de planta. Produtividade de grãos.

\section{REFERENCES}

BREDEMEIER, C.; MUNDSTOCK, C. M. Estádios fenológicos do trigo para a adubação nitrogenada em cobertura. Revista Brasileira de Ciência do Solo, Viçosa, v. 25, n. 2, p. 317-323, 2001. 
COELHO, M. A. O.; SOUZA, M. A.; SEDIYAMA, T.; RIBEIRO, A. C.; SEDIYAMA, C. S. Resposta da produtividade de grãos e outras características agronômicas do trigo EMBRAPA-22 irrigado ao nitrogênio em cobertura. Revista Brasileira de Ciência do Solo, Viçosa, v. 22, p. 555-561, 1998.

COMISSÃO DE QUÍMICA E FERTILIDADE DO SOLO (CQFS RS/SC). Manual de adubação e calagem para os estados do Rio Grande do Sul e Santa Catarina. 10ed. Porto Alegre: Sociedade Brasileira de Ciência do Solo/Núcleo Regional Sul, 2004. 400 p.

DATE, R. A. Inoculated legumes in cropping systems of the tropics. Field Crops Research, Amsterdam, v. 65, p. 123-136, 2000. http://dx.doi.org/10.1016/S0378-4290(99)00082-9

EMPRESA BRASILEIRA DE PESQUISA AGROPECUÁRIA - EMBRAPA. Tecnologias de produção de soja - região central do Brasil - 2007. Londrina: Embrapa Soja, Embrapa Cerrados, Embrapa Agropecuária Oeste, 2006. 225 p. (Sistemas de Produção).

ESPINDULA, M. C.; ROCHA, V. S.; SOUZA, M. A. et al. Doses e formas de aplicação de nitrogênio no desenvolvimento e produção da cultura do trigo. Ciência Agrotécnica, Lavras, v. 34, n. 6, p. 1404-1411, 2010.

GRAHAM, P. H.; VANCE, C. P. Nitrogen fixation in perspective: an overview of research and extension needs. Field Crops Research, Amsterdam,v. 65, p. 93-106, 2000. http://dx.doi.org/10.1016/S03784290(99)00080-5

HERINGER, I; MOOJEN, E. L. Potencial produtivo, alterações da estrutura e qualidade da pastagem de milheto submetida a diferentes Níveis de Nitrogênio. Revista Brasileira de Zootecnia, Viçosa, v. 31, n. 2, p. 875-882, 2002.

JORNADA, J. B. J.; MEDEIROS, R. B.; PEDROSO, C. E. S. et al. Efeito da irrigação, épocas de corte da forragem e doses de nitrogênio sobre o rendimento de sementes de milheto. Revista Brasileira de Sementes, Brasília, v. 27, n. 2, p. 50-58, 2005. http://dx.doi.org/10.1590/S0101-31222005000200008

MEGDA, M. M.; BUZETTI, S.; ANDREOTTI, M. et al. Resposta de cultivares de trigo ao nitrogênio em relação às fontes e épocas de aplicação sob plantio direto e irrigação por aspersão. Ciência e Agrotecnologia, Lavras, v. 33, n. 4, p. 1055-1060, 2009.

RAMBO, L.; SILVA, P .R. F. da; ARGENTA, G.; SANGOI, L. Parâmetros de planta para aprimorar o manejo da adubação nitrogenada de cobertura em milho. Ciência Rural, Santa Maria, v. 34, p. 1637-1645, 2004.

SANGOI, L.; BERNS, A. C.; ALMEIDA, M. L. et al. Características agronômicas de cultivares de trigo em resposta à época da adubação nitrogenada de cobertura. Ciência Rural, Santa Maria, v. 37, n. 6, p. 1564-1570, 2007. http://dx.doi.org/10.1590/S0103-84782007000600010

SIMILI, F. F.; REIS, R. A.; FURLAN, B. N. et al. Resposta do híbrido de sorgo-sudão à adubação nitrogenada e potássica: composição química e digestibilidade in vitro da matéria orgânica. Ciência e Agrotecnologia, Lavras, v. 32, n. 2, p. 474-480, 2008. http://dx.doi.org/10.1590/s1413-70542008000200020

SORATTO, R. P.; LIMA, E. V.; SILVA, T. R. B. et al. Nitrogen fertilization of fall panicum cultivars (Panicum dichotomiflorum Michx.): biochemical and agronomical aspects. Scientia Agricola, Piracicaba, v. 61, n. 1, p. 82-87, 2004.

SORATTO, R. P.; CARDOSO, S. M.; SILVA, Â. H. et al. Doses e épocas de aplicação de nitrogênio em cobertura na cultura do painço (Panicum miliaceum L.). Ciência e Agrotecnologia, Lavras, v. 31, n. 6, p. 1661-1667, 2007.

TEDESCO, M. J. et al. Análise de solo, plantas e outros materiais. Porto Alegre, Universidade Federal do Rio Grande do Sul, 1995. 174 p. 
WAMSER, A. F.; MUNDSTOCK, C. M. Adubação nitrogenada em estádios fenológicos em cevada, cultivar "MN 698”. Ciência Rural, Santa Maria, v. 37, n. 4, p. 942-948, 2007. http://dx.doi.org/10.1590/S010384782007000400004

ZANCANELLA, E. F.; BONATTI, J. L.; MARTUCCI, L. M. V. Cultura do painço: informações práticas. Campinas: CATI, 2003. 4 p. (Folheto). 